Abstracta Iranica Abstracta Iranica

Revue bibliographique pour le domaine irano-aryen

Volume 32-33 | 2013

Comptes rendus des publications de 2009-2010

\title{
Askold Ivantchik, Alexander von Kienlin, Lâtife Summerer. Recherches à Kélainai - Apamée Kibôtos en 2008-2009. Rapport préliminaire
}

\section{Astrid Nunn}

\section{(2) OpenEdition \\ 1 Journals}

\section{Édition électronique}

URL : http://journals.openedition.org/abstractairanica/40299

DOI : 10.4000/abstractairanica.40299

ISSN : 1961-960X

Éditeur :

CNRS (UMR 7528 Mondes iraniens et indiens), Éditions de l'IFRI

\section{Édition imprimée}

Date de publication : 1 décembre 2013

ISSN : 0240-8910

Référence électronique

Astrid Nunn, «Askold Ivantchik, Alexander von Kienlin, Lâtife Summerer. Recherches à Kélainai Apamée Kibôtos en 2008-2009. Rapport préliminaire », Abstracta Iranica [En ligne], Volume 32-33 | 2013, document 79, mis en ligne le 01 juillet 2016, consulté le 03 octobre 2020. URL : http:// journals.openedition.org/abstractairanica/40299; DOI : https://doi.org/10.4000/abstractairanica. 40299

Ce document a été généré automatiquement le 3 octobre 2020.

Tous droits réservés 
Askold Ivantchik, Alexander von Kienlin, Lâtife Summerer. Recherches à Kélainai - Apamée Kibôtos en 2008-2009. Rapport préliminaire

Astrid Nunn 


\section{RÉFÉRENCE}

Askold Ivantchik, Alexander von Kienlin, Lâtife Summerer. « Recherches à Kélainai Apamée Kibôtos en 2008-2009. Rapport préliminaire ». Anatolia Antiqua XVIII, 2010, p. 109-140.

Le projet cofinancé par l'ANR et la DFG sur l'emplacement de l'antique Kélainai Apamée Kibôtos, situé à la périphérie nord-est de la ville turque de Dinar, a débuté en 2008. Les résultats présentés dans ce rapport sont basés sur des prospections de terrain. Des tessons de coupes achéménides révèlent que la colline principale était certainement habitée bien avant la «fondation » hellénistique d'Antiochos Soter. À l'est de la colline principale, et séparée d'elle par une grande voie routière, se situe une zone rocheuse sur laquelle se trouvaient de la céramique et des pointes de flèche qui confirment la présence d'une fortification dès l'époque achéménide. Cette zone correspond en outre à une des possibles localisations du palais de Xerxès mentionné dans les sources grecques. Une monnaie achéménide mise à disposition par un habitant de Dinar pourrait provenir d'un trésor de sigles perses découvert il y a environ 15 ans à Dinar (I. A. Carradice, « The Dinar Hoard of Persian Sigloi », in : R. Ashton, S. Hurter in association with G. Le Rider, R. Bland, eds., Studies in Greek Numismatics in Memory of Martin Jessop Price, London, 1998, p. 65-81, pl.17-20). D'autres sites autour de Dinar étaient également habités à l'époque achéménide.

\section{AUTEURS}

\section{ASTRID NUNN}

Université de Munich 